\title{
The Formation of Ribulose 1:5-Diphosphate Carboxylase by Growing Cultures of Athiorhodaceae
}

\author{
Bx JUNE LASCELLES \\ Microbiology Unit, Department of Biochemistry, University of Oxford
}

(Received 10 May 1960)

\begin{abstract}
SUMMARY
Ribulose 1:5-diphosphate carboxylase, which catalyses the conversion of ribulose 1:5-diphosphate and $\mathrm{CO}_{2}$ to 3-phosphoglyceric acid, is a key enzyme in the reductive pentose cycle. It was formed only in traces by Rhodopseudomonas spheroides growing in the dark under conditions of high or low aeration but organisms grown photosynthetically were rich in the enzyme. The activity of some other enzymes of the cycle, phosphoriboisomerase, phosphoglyceric acid kinase and triosephosphate dehydrogenase (diphosphopyridine nucleotide-linked) did not vary significantly with the growth conditions. The differential rate of synthesis (increase in enzyme/ increase in culture density) of the carboxylase was studied in cultures of $\boldsymbol{R}$. spheroides growing exponentially under various conditions. It was influenced by the light intensity, being decreased when this was increased. Oxygen completely repressed formation of the enzyme even under continuous illumination; this effect was annulled by restoration of anaerobic conditions. Dark-grown organisms formed the enzyme at a high differential rate immediately on transfer to anaerobic +light conditions, provided that they contained a minimal amount of bacteriochlorophyll. Biotin deficiency did not affect the synthesis of the carboxylase. The conditions which promoted carboxylase formation were in many respects similar to those favourable to synthesis of enzymes required for the early stages of bacteriochlorophyll formation. The connexion of these observations with the regulation of pigment synthesis and with the possible physiological role of the enzyme in the Athiorhodaceae is discussed.
\end{abstract}

\section{INTRODUCTION}

The enzyme (RuDP carboxylase) catalysing the formation of 3-phosphoglyceric acid from ribulose 1:5-diphosphate $(\mathrm{RuDP})$ and $\mathrm{CO}_{2}$ is a key one in the reductive pentose cycle (Bassham \& Calvin, 1957) and was first demonstrated in preparations from algae (Quayle, Fuller, Benson \& Calvin, 1954; Weissbach, Smyrniotis \& Horecker, 1954). Its presence has since been shown either directly or indirectly in many autotrophic bacteria (Trudinger, 1956; Aubert, Milhaud \& Millet, 1957; Vishniac \& Santer, 1957; Bergmann, Towne \& Burris, 1958; Kornberg, Collins \& Bigley, 1960) as well as in Pseudomonas oxalaticus growing on formate (Quayle \& Keech, $1959 a, b)$. The operation of the reductive pentose cycle in photosynthetic bacteria was suggested originally by observations that 3-phosphoglyceric acid appeared as an early product of ${ }^{14} \mathrm{CO}_{2}$ fixation by Rhodospirillum rubrum and 
Rhodopseudomonas capsulatus; this occurred when organisms harvested after photosynthetic growth were incubated anaerobically in light or aerobically in dark in the presence of oxidizable substrates (Glover, Kamen \& van Genderen, 1952; Stoppani, Fuller \& Calvin, 1955). The presence of RuDP carboxylase has since been directly demonstrated in extracts of Rhodospirillum rubrum and Chromatium sp. (Fuller \& Gibbs, 1959).

RuDP carboxylase is formed by chemosynthetic organisms, which use either hydrogen or organic substrates, only under conditions of autotrophic growth (Vishniac \& Santer, 1957; Kornberg et al. 1960). It is also formed adaptively by Pseudomonas oxalaticus in response to formate, which is assimilated via the reductive pentose pathway, but oxalate (which is assimilated by a different route) does not induce the enzyme (Quayle \& Keech, $1959 a, b ; 1960$ ). The carboxylase is also adaptive in algae and is found only in organisms grown in the light with $\mathrm{CO}_{2}$ as carbon source (Fuller \& Gibbs, 1959).

It seemed probable that the formation of RuDP carboxylase by the Athiorhodaceae might also be influenced by the environment; many of these organisms are capable of aerobic growth in the dark on the same organic substrates that are utilized for photosynthetic development (van Niel, 1944). In the present work a study has been made of the effect of various factors on RuDP carboxylase formation in exponentially growing cultures of Rhodopseudomonas spheroides; conditions for synthesis of the enzyme have been found to be similar to those shown previously to favour formation of bacteriochlorophyll and enzymes concerned in the early stages of tetrapyrrole synthesis (Lascelles, 1960).

\section{METHODS}

Organisms. Rhodopseudomonas spheroides (NCIB no. 8253) and $R$. palustris (strain 2.1.7 from the collection of Professor C. B. van Niel) were used. Stock cultures of both were maintained as described previously (Lascelles, 1956).

Media. Unless stated otherwise all experiments with $R$ hodopseudomonas spheroides were made with cultures grown in a chemically defined medium containing malate and glutamate supplemented with 0.01 mu-iron citrate (Lascelles, 1959). p-Aminobenzoate $(0.001 \mathrm{~mm})$ was added to this medium for growth of $\boldsymbol{R}$. palustris. In one experiment, shown in Table $1, R$. spheroides was grown on a medium containing sodium butyrate $(0.01 \mathrm{M})$ and sodium bicarbonate $(0.006 \mathrm{M})$ in place of malate and glutamate.

Growth of cultures. The methods used to obtain exponentially growing cultures and the standard conditions for anaerobic incubation in the light and for aerobic incubation in the dark under conditions of high and low aeration are described in the previous paper (Lascelles, 1960); growth was also assessed in the way there indicated.

Preparation of cell-free extracts. Samples were taken from cultures and extracts prepared from the harvested organisms as described previously (Lascelles, 1960).

Estimation of bacteriochlorophyll and protein. These were determined by the methods described by Lascelles (1959).

Assays of enzymic activity. RuDP carboxylase was assayed by a method based on that described by Racker (1957) in which the reaction product, 3-phosphoglyceric 
acid, is estimated spectrophotometrically in the presence of reduced diphosphopyridine nucleotide (DPNH), adenosine triphosphate (ATP), 3-phosphoglyceric acid kinase, and triosephosphate dehydrogenase. The assay mixture contained: extract of organisms (0.1-0.5 mg. protein); 2-amino-2-hydroxymethylpropane-1:3-

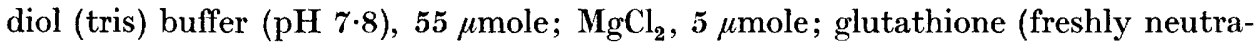
lized), $6 \mu$ mole; $\mathrm{NaHCO}_{3}, 40 \mu$ mole; RuDP (potassium salt), $0.5 \mu$ mole; water to $1.0 \mathrm{ml}$. The mixtures were incubated for $10 \mathrm{~min}$. at $30^{\circ}$ and the reaction stopped by adding $0.02 \mathrm{ml} . \mathrm{N}-\mathrm{HCl}$ and heating at $100^{\circ}$ for $2 \mathrm{~min}$. After centrifugation, the 3-phosphoglyceric acid formed was estimated in samples of the supernatant fluid. For this purpose micro-cuvettes $(1 \mathrm{~cm}$. light path, $0.4 \mathrm{ml}$. capacity) were filled as follows: sample, $0.2 \mathrm{ml}$; tris buffer ( $\mathrm{pH} 7 \cdot 8$ ), $25 \mu$ mole; $\mathrm{MgCl}_{2}, 2.5 \mu$ mole; L-cystein (freshly neutralized), $3 \mu$ mole; crystalline triosephosphate dehydrogenase, $25 \mu \mathrm{g}$.; ATP, $0.3 \mu$ mole; DPNH, $0.056 \mu$ mole; water to final volume $0.4 \mathrm{ml}$. After taking the initial reading at $340 \mathrm{~m} \mu$ (against the control cuvette containing the complete reaction mixture without DPNH) the reaction was started by addition of 3-phosphoglyceric acid kinase (2.5 $\mu \mathrm{g}$.). Readings were taken until there was no further decline in extinction at $340 \mathrm{~m} \mu(5-10 \mathrm{~min}$.) and the amount of 3-phosphoglyceric acid in the sample calculated from the amount of DPNH oxidized; $10 \mu \mathrm{m}$-mole of 3-phosphoglyceric acid caused a decline in extinction of $0 \cdot 155$. Controls without bicarbonate were included in each assay and the 3-phosphoglyceric acid formed was deducted from the experimental value; the amount was small and did not exceed $15 \mu \mathrm{m}-\mathrm{mole} / \mathrm{mg}$. of protein of the extract. One unit of enzyme is defined as the amount which catalyses the formation of $1 \mu \mathrm{m}$-mole of 3-phosphoglyceric acid under the standard conditions of assay.

Phosphoriboisomerase, which catalyses the conversion of ribose-5-phosphate to ribulose-5-phosphate, was assayed by the method described by Horecker, Hurwitz $\&$ Weissbach (1958) except that incubation was for $10 \mathrm{~min}$. at $30^{\circ}$. One unit of enzyme is defined as the amount catalysing the formation of $1 \mu \mathrm{m}$-mole ketopentose under the standard conditions.

Triosephosphate dehydrogenase and 3-phosphoglyceric acid kinase were assayed spectrophotometrically at $340 \mathrm{~m} \mu$ by following the rate of oxidation of DPNH in the presence of 3-phosphoglyceric acid, ATP and excess of one or other of these enzymes (Bücher, 1947). For assay of the dehydrogenase, cuvettes $(1 \mathrm{~cm}$. light path, $4 \mathrm{ml}$. total capacity) were filled as follows: extract of organisms $(0 \cdot 05-0 \cdot 1 \mathrm{mg}$. protein); tris buffer (pH 8.2), $40 \mu$ mole; L-cystein (freshly neutralized), $12 \mu$ mole; ATP, $2 \mu$ mole; DPNH, $0 \cdot 3 \mu$ mole (except in the blank); 3-phosphoglyceric acid kinase, $5 \mu \mathrm{g}$; ; water to final volume $3.1 \mathrm{ml}$. The reaction was started by adding $10 \mu$ mole 3 -phosphoglyceric acid and readings at $340 \mathrm{~m} \mu$ were taken at $1 \mathrm{~min}$. intervals to determine the rate of DPNH oxidation. 3-Phosphoglyceric acid kinase was estimated in the same way except that the assay mixture contained triosephosphate dehydrogenase $(10 \mu \mathrm{g}$.) in place of the kinase. One unit of either enzyme is the amount which catalyses a decline in extinction of $0 \cdot 10$ in 2 min. under the standard conditions.

$\delta$-Aminolaevulic acid synthetase (ALA synthetase) was assayed as described previously (Lascelles, 1960).

All spectrophotometric determinations were made with the Unicam spectrophotometer, Model SP 500. 
Expression of results. As in the previous paper (Lascelles, 1960) most of the results are presented as the differential rate of enzyme synthesis, i.e. the ratio of increase in enzyme to increase in culture density (Monod, Pappenheimer \& Cohen-Bazire, 1952).

Materials. Ribulose 1:5-diphosphate (potassium salt) was prepared from ribose5-phosphate and ATP by the action of phosphoriboisomerase and phosphoribulokinase; the methods of preparation of the phosphate ester and the enzymes (from spinach) were as described by Horecker et al. (1958). The potassium salts of ribose-5-phosphate and 3-phosphoglyceric acid were made from the barium salts (British Drug Houses Ltd., Poole, Dorset) by treatment with Dowex-50 ( $\mathbf{H}^{+}$form) and neutralization with N-KOH. Adenosine triphosphate, DPNH and triphosphopyridine nucleotide (TPNH) were from the Sigma Chemical Co. (St Louis, Mo., U.S.A.). Crystalline triosephosphate dehydrogenase and 3-phosphoglyceric acid kinase were purchased from Boehringer \& Soehne (Mannheim, Germany).

\section{RESULTS}

\section{Effect of light on the production of various enzymes}

Enzymes in Rhodopseudomonas spheroides. Extracts of organisms harvested after anaerobic growth in light were rich in RuDP carboxylase, but only traces of this enzyme were found in those from cultures which had been grown in the dark under high aeration (Table 1). There was little difference in the amount of RuDP

Table 1. Activity of enzymes in extracts of Rhodopseudomonas spheroides and

\section{$\mathbf{R}$. palustris grown under various conditions}

Extracts were prepared from organisms harvested during the logarithmic phase of growth under the conditions described in the Methods. The results shown are the mean values obtained with at least two extracts of each type.

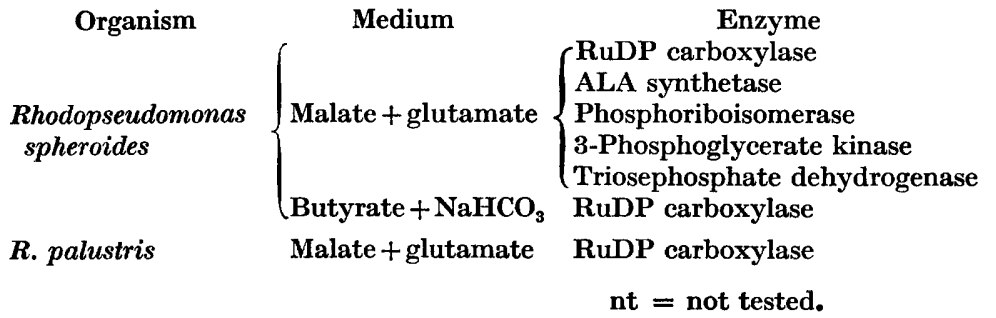

\begin{tabular}{|c|c|c|}
\hline \multicolumn{3}{|c|}{$\begin{array}{l}\text { Activity in extracts from } \\
\text { organisms grown }\end{array}$} \\
\hline \multicolumn{2}{|c|}{ Dark } & $\begin{array}{l}\text { aerobic }+ \\
\text { light }\end{array}$ \\
\hline $\begin{array}{l}\text { Low } \\
\text { aeration } \\
\text { (units e }\end{array}$ & $\begin{array}{c}\text { High } \\
\text { aeration } \\
\text { azyme/mg }\end{array}$ & rotein) \\
\hline 15 & 10 & 300 \\
\hline 122 & 16 & 150 \\
\hline nt & 435 & 520 \\
\hline nt & $0 \cdot 11$ & $0 \cdot 12$ \\
\hline nt & $0 \cdot 76$ & 0.71 \\
\hline nt & $<10$ & 342 \\
\hline nt & 82 & 273 \\
\hline
\end{tabular}

carboxylase in organisms grown in the dark under either low or high aeration; this is in contrast to the ALA synthetase, the activity of which is high in organisms grown under low aeration (Table 1).

Rhodopseudomonas spheroides, like other members of the Athiorhodoaceae, requires added bicarbonate for growth on fatty acids even under aerobic conditions (van Niel, 1941) and the activity of RuDP carboxylase was therefore examined in 
extracts of organisms grown on these substrates. The amount of the enzyme was, however, just as low in extracts of bacteria grown aerobically on media containing butyrate+bicarbonate in place of malate+glutamate; extracts from photosynthetically-grown cultures on either medium had similar activity (Table 1). Similar results were obtained with extracts from cultures on acetate + bicarbonate.

The growth conditions did not significantly affect the activity of enzymes involved at other stages in the reductive pentose cycle. Phosphoriboisomerase, 3-phosphoglycerate kinase and triosephosphate dehydrogenase had similar activities in extracts of organisms grown either in the light or in the dark (Table 1). The triosephosphate dehydrogenase in organisms grown aerobically or photosynthetically reacted only with DPNH and there was no sign of activity with TPNH. This is in contrast to green plants which contain both di- and triphosphopyridine nucleotidelinked triosephosphate dehydrogenases (Gibbs, 1952; Arnon, Rosenberg \& Whatley, 1954).

RuDP carboxylase in Rhodopseudomonas palustris. This organism, like $\boldsymbol{R}$. spheroides, grows both aerobically and photosynthetically, forming bacteriochlorophyll under the latter conditions. Appreciable RuDP carboxylase was found in extracts of aerobically-grown organisms, but it was only $c .30 \%$ of that in extracts from bacteria grown anaerobically in light (Table 1).

\section{The differential rate of synthesis of ribulose diphosphate carboxylase} by Rhodopseudomonas spheroides

Effect of light intensity. Cultures of Rhodopseudomonas spheroides growing anaerobically in light under the standard conditions formed RuDP carboxylase at a fairly constant differential rate, which varied from 140 to 200 units/mg. dry wt. organism in different experiments. This was decreased by a factor of two or more when the illumination was increased by changing the light source from a $100 \mathrm{~W}$. lamp to a $275 \mathrm{~W}$. photoflood lamp (Fig. 1). Such a change also results in decreases in the differential rate of synthesis of both bacteriochlorophyll and ALA synthetase (Lascelles, 1960).

Effect of $\mathrm{O}_{2}$. Synthesis of RuDP carboxylase ceased abruptly when cultures growing anaerobically in light were transferred to the dark and the incubation continued aerobically (Fig. 2). Cessation of synthesis under these conditions might have been due to the absence of light or to the presence of oxygen; to determine this, formation of the carboxylase was examined in cultures growing under continuous illumination but with changes in the gas phase. Synthesis of the enzyme stopped completely when the gas phase of $5 \%(\mathrm{v} / \mathrm{v}) \mathrm{CO}_{2}$ in $\mathrm{N}_{2}$ was replaced by one of $5 \%(\mathrm{v} / \mathrm{v}) \mathrm{CO}_{2}$ in air, though growth continued at the same rate (Fig. 3). This change was reversible, enzyme synthesis being resumed at the same differential rate when the gas phase was changed back to $5 \%(\mathrm{v} / \mathrm{v}) \mathrm{CO}_{2}$ in $\mathrm{N}_{2}$ (Fig. 3). The effect of $\mathrm{O}_{2}$ on the formation of the carboxylase enzyme is therefore similar to its action on synthesis of bacteriochlorophyll and ALA synthetase (Lascelles, 1960).

Enzyme synthesis by Rhodopseudomonas spheroides adapting from aerobicto photosynthetic conditions. The formation of RuDP carboxylase and bacteriochlorophyll was examined in cultures of $R$. spheroides which were adapting from aerobic growth in the dark to anaerobic growth in light. When organisms harvested after growth in the 
dark under high aeration were resuspended in fresh medium and incubated anaerobically in light, growth occurred after a lag of about $14 \mathrm{hr}$. (Fig. 4a). Such organisms initially contain only traces of bacteriochlorophyll and growth cannot occur until sufficient pigment has been made for the bacteria to obtain energy from the light. The development of RuDP carboxylase in such cultures occurred simultaneously with the formation of bacteriochlorophyll (Fig. $4 a$ ).

A different situation was found when aerobically grown organisms were subjected to a short period of incubation under low aeration in the dark before transferring to anaerobic conditions in light. The preliminary incubation resulted in a 16-fold increase in the concentration of bacteriochlorophyll in the organisms (from $0 \cdot 18$ to

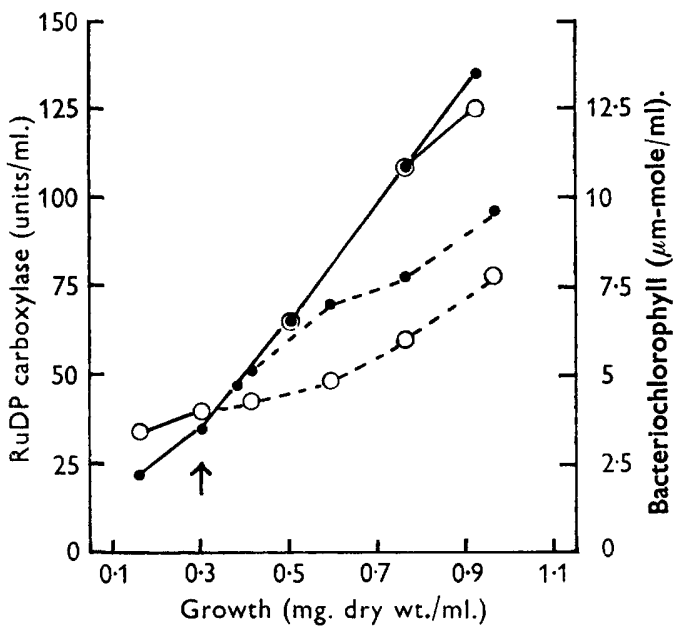

Fig. 1

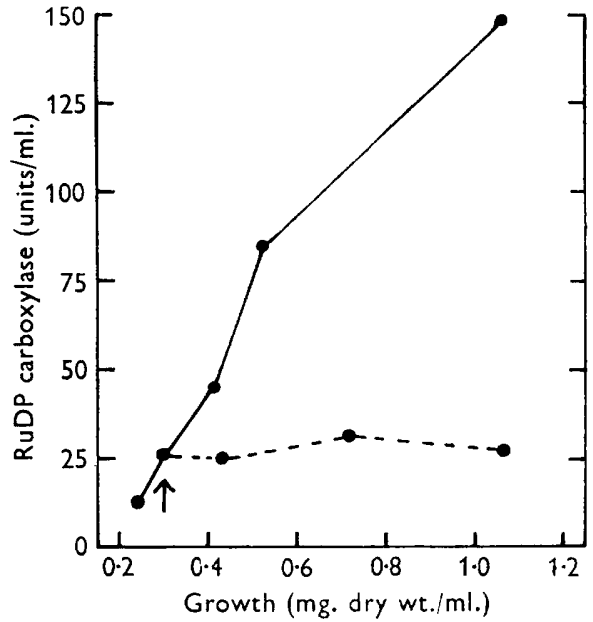

Fig. 2

Fig. 1. Effect of light intensity on synthesis of RuDP carboxylase (-0-) and bacteriochlorophyll (- - ) by Rhodopseudomonas spheroides. Organisms harvested after anaerobic growth in light were resuspended in fresh medium and incubated for $\mathbf{2 \cdot 2 5} \mathrm{hr}$. anaerobically in light under standard conditions. At the point shown by the arrow the culture was divided and one half incubated in front of a $275 \mathrm{~W}$. photoflood lamp (broken lines); the other half was continuously incubated under the standard conditions (100 W. lamp).

Fig. 2. Effect of aerobic incubation in the dark on synthesis of RuDP carboxylase. Organisms harvested after anaerobic growth in the light were resuspended in fresh medium and incubated for one hour anaerobically in the light under standard conditions. At the stage shown by the arrow the culture was divided, one half being further incubated in the dark under high aeration (broken lines), the other half (full lines) being continuously incubated anaerobically in the light.

$2.9 \mu \mathrm{m}$-mole/mg. dry wt.) but there was no detectable increase in the RuDP carboxylase. On changing to anaerobic conditions in light there was a lag of 1-2 hr. before the rate of growth and bacteriochlorophyll formation became maximal, but synthesis of RuDP carboxylase occurred without a detectable lag (Fig. $4 b$ ). Thus, initially the enzyme was formed at a greater rate than the total protein of the organisms, as shown by the high differential rate; this decreased to the usual value when the culture entered the exponential phase of growth (Fig. 5). Bacteriochlorophyll was formed at a constant differential rate throughout (Fig. 5). 


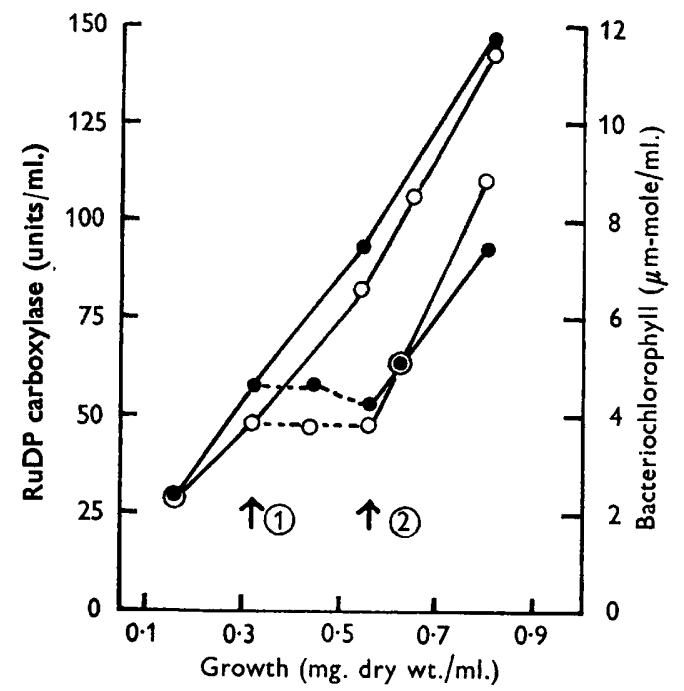

Fig. 3. Effect of oxygen on synthesis of RuDP carboxylase (- - ) and bacteriochlorophyll $(-\mathrm{O}-$ ) by illuminated cultures. Organisms were harvested after anaerobic growth in the light, resuspended in fresh medium and incubated for $2 \mathrm{hr}$. anaerobically in the light under standard conditions. At the point shown by arrow (1) the culture was divided. One part was aerated with air- $\mathrm{CO}_{2}(95: 5)$ for a further $1 \cdot 75 \mathrm{hr}$. (broken lines) and at the point shown by arrow (2) the gas phase was changed back to $\mathrm{N}_{2}-\mathrm{CO}_{2}$. The other part of the culture (full lines) was kept continuously under $\mathrm{N}_{2}-\mathrm{CO}_{2}$. All cultures were incubated with continuous illumination.
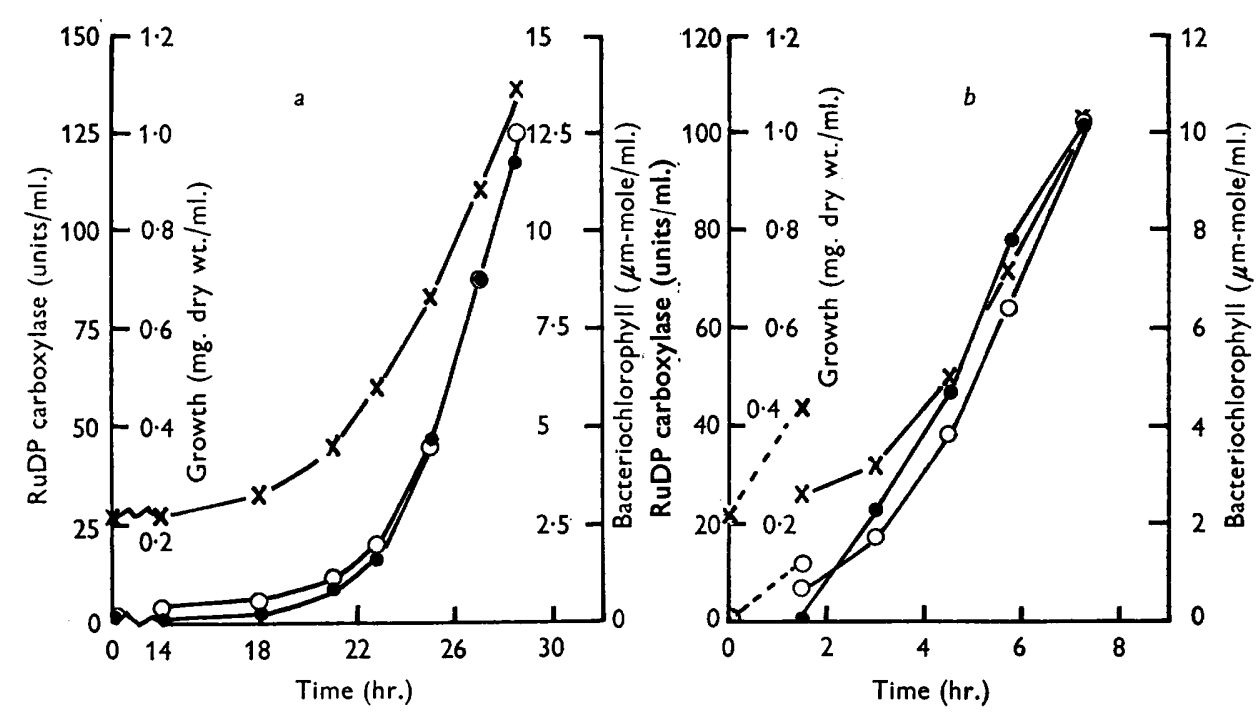

Fig. 4a,b. The rates of growth $(-\times-)$ and synthesis of RuDP carboxylase (-0 - ) and of bacteriochlorophyll $\left(-\mathrm{O}_{-}\right)$in cultures transferred from aerobic-dark to anaerobiclight conditions. Organisms were harvested after growth in the dark under high aeration and resuspended in fresh medium. One portion $(a)$ was transferred immediately to anaerobic conditions in the light. The other portion $(b)$ was incubated first for $90 \mathrm{~min}$. in the dark under low aeration (broken lines), the bacteria harvested and resuspended in fresh medium and then incubated anaerobically in the light (full lines). 
The effect of biotin deficiency in Rhodopseudomonas spheroides

Since biotin is known to be involved in some enzymes concerned with the transfer of $\mathrm{CO}_{2}$ (Lynen, Knappe, Lorch, Jütting \& Ringelmann, 1959) the effect of biotin deficiency on the activity of RuDP carboxylase was examined. The activity of this enzyme was, however, the same in extracts from biotin-deficient organisms (grown with one-fiftieth the usual concentration of biotin) as in those from normal organisms (Table 2). The ALA synthetase activity in the deficient extracts was only c. $30 \%$ of the normal value (Table 2).

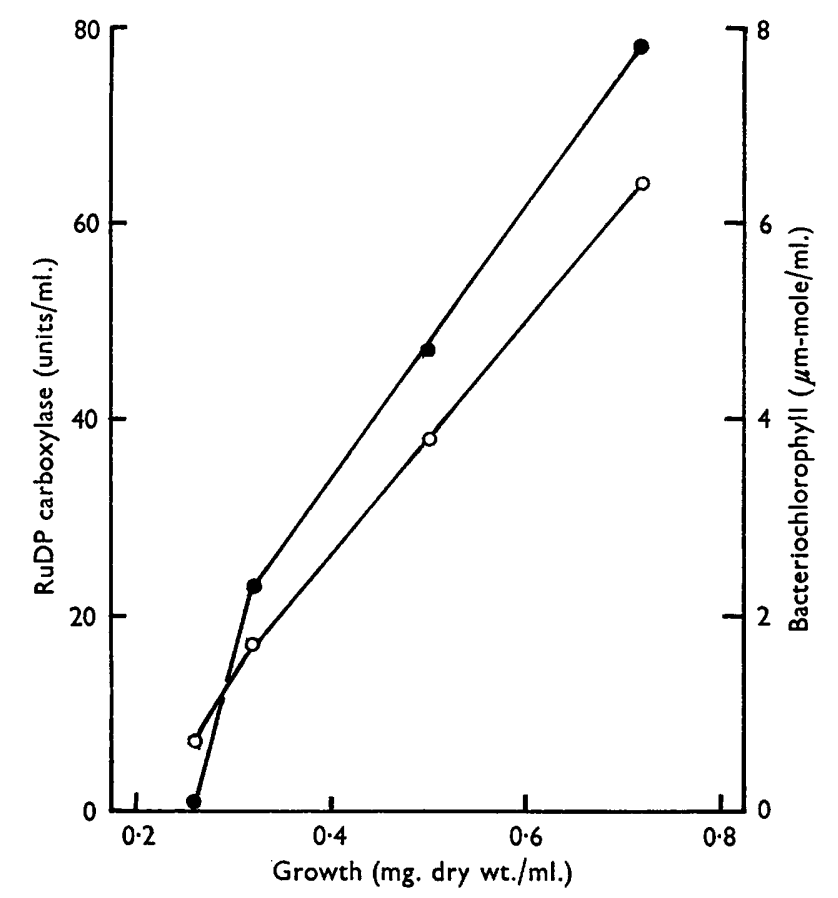

Fig. 5. The differential rate of synthesis of RuDP carboxylase (-0-) and bacteriochlorophyll ( $\mathrm{O}-$ ) on transfer of 'pretreated' cultures to anaerobic conditions in the light. The experiment is that described in Fig. $4 b$ after the cultures had been incubated for $90 \mathrm{~min}$. in the dark under low aeration.

Table 2. Effect of biotin deficiency on the activity of RuDP carboxylase and $A L A$ synthetase in Rhodopseudomonas spheroides

Extracts were prepared from $R$.spheroides harvested after anaerobic growth in light from cultures containing 0.2 or $10 \mu \mathrm{g}$. $/ 1$. of biotin (deficient and normal extracts, respectively). The activities of RuDP carboxylase and ALA synthetase were assayed by the standard procedures.

$\begin{array}{lcc}\text { Extract } & \overbrace{\begin{array}{c}\text { RuDP carboxylase } \\ \text { (units enzyme/mg. protein) }\end{array}}^{\text {Activity of }} \\ \begin{array}{lc}\text { Deficient } \\ \text { Normal }\end{array} & \mathbf{3 2 0} & \mathbf{4 4} \\ \text { A40 } & \mathbf{1 4 0}\end{array}$




\section{DISCUSSION}

The function of RuDP carboxylase in autotrophs and in Pseudomonas oxalaticus (on formate) is clear: it is essential for conversion of $\mathrm{CO}_{2}$ to cell substance by the reductive pentose cycle. Its role in the Athiorhodaceae, which require organic carbon for growth, is less obvious; experiments with ${ }^{14} \mathrm{CO}_{2}$ have shown that its contribution to total cell carbon is relatively slight, the major proportion being "derived from the organic substrate (Cutinelli, Ehrensvärd, Reio, Saluste \& Stjernholm, 1951; Ormerod, 1956; Stanier, Doudoroff, Kunisawa \& Contopoulou, 1959). Yet $\mathrm{CO}_{2}$ plays an essential part in their metabolism and must be added to cultures or washed suspensions for utilization of reduced substrates such as fatty acids (Gaffron, 1933, 1935; van Niel, 1941; Stanier et al. 1959). The isotope experiments have shown that it is fixed primarily into 3-phosphoglyceric acid, at least by washed suspensions of photosynthetically-grown organisms (Glover et al. 1952; Stoppani et al. 1955); this suggests that the carboxylase does function normally in these bacteria. It is possible that its major physiological role in the Athiorhodaceae is to render $\mathrm{CO}_{2}$ available in a form which can act as a $\mathrm{H}$-acceptor under anaerobic conditions. Thus, reduction of the product of RuDP carboxylase action, 3-phosphoglyceric acid, to triose phosphate may be an important outlet for the DPNH generated by oxidation of the organic substrate. This could provide an explanation (albeit teleological) for the repressing effect of oxygen, an alternative $\mathbf{H}$-acceptor which abolishes the need for $\mathrm{CO}_{2}$ as ultimate oxidant.

The fact that the RuDP carboxylase is an adaptive enzyme in Rhodopseudomonas spheroides, being formed only by cultures growing anaerobically in light, supports the suggestion that the enzyme has an important function under these conditions. Enzyme synthesis occurs immediately on transfer of organisms from aerobic + dark to anaerobic + light conditions, provided that the organisms contain adequate amounts of bacteriochlorophyll. The intracellular concentration of bacteriochlorophyll does not have to be high to permit synthesis of RuDP carboxylase. In the experiment shown in Figs. 4 and 5 the initial amount of pigment $(2.9 \mu \mathrm{m}$ mole/mg. dry wt. organism) was only about one-fifth of the maximum amount in organisms growing anaerobically in light under standard conditions; yet, enzyme synthesis began immediately at a high differential rate on exposure to anaerobic + light conditions. Similar results have been obtained with organisms containing initially as little as $1 \mu \mathrm{m}$-mole of bacteriochlorophyll/mg. dry wt. The rapid synthesis of the enzyme, which occurs provided that the organisms have sufficient pigment to utilize light energy, is similar to observations with Pseudomonas oxalaticus; synthesis of the enzyme occurs before the organism begins to grow on transfer of cultures from oxalate to formate, the energy for its synthesis being provided by oxidation of formate (Quayle \& Keech, 1960).

The conditions which promote synthesis of the RuDP carboxylase are similar in several respects to those which favour bacteriochlorophyll formation. Thus, the differential rate of synthesis of the enzyme and pigment is decreased at high light intensities and oxygen completely represses their formation even in the presence of light. On the other hand, incubation in the dark under low aeration did not permit synthesis of RuDP carboxylase though pigment is formed. It seems therefore that active carboxylase is made only in an environment which 
promotes both the formation and the normal functioning of bacteriochlorophyll.

The hypothesis of Cohen-Bazire, Sistrom \& Stanier (1957) that pigment synthesis is regulated by the state of oxidation of a carrier in the electron transport chain might also apply to the control of RuDP carboxylase formation; different components in the chain might act in each case. This hypothesis could account both for the effect of light intensity and of oxygen. There is now ample evidence, derived from spectroscopic observations of whole organisms and extracts of photosynthetic bacteria, that both illumination and aeration affect the amounts of oxidized and reduced forms of the cytochromes (Frenkel, 1959; Smith \& Ramírez, 1959; Smith, Baltscheffsky \& Olson, 1960). The amount of DPNH in photosynthetic bacteria is also influenced by illumination (Olson, Duysens \& Kronenberg, 1959; Olson \& Amesz, 1960). A step towards demonstrating the validity of the hypothesis of Cohen-Bazire et al. (1957) would be to correlate one or other of these changes with synthesis of enzymes and pigments. The hypothesis may also be applicable to the adaptive synthesis of RuDP carboxylase in non-photosynthetic bacteria. In the examples studied synthesis of the enzyme is associated with the substrate used as energy source, growth on hydrogen invoking its formation in Hydrogenomonas spp. and Micrococcus denitrificans (Vishniac \& Santer, 1957; Kornberg et al. 1960) and on formate in Pseudomonas oxalaticus (Quayle \& Keech, 1960). The steady state concentrations of reduced and oxidized forms of components of the electron transport chain may differ according to the substrate being oxidized and such differences have, in fact, been shown spectroscopically in Hydrogenomonas ruhlandii oxidizing hydrogen or lactate (Packer, 1958).

I wish to thank Professor D. D. Woods, F.R.S. for his interest and encouragement. I am greatly indebted to Dr D. B. Keech, Dr J. R. Quayle and Dr F. R. Whatley for valuable advice and to $\mathrm{Mr}$ R. Wakelin for preparing the ribulose 1:5-diphosphate. The work was supported by a grant to the Department from the Rockefeller Foundation. The author is a member of the External Scientific Staff of the Medical Research Council.

\section{REFERENCES}

Arnon, D. I., Rosenberg, L. L. \& Whatley, F. R. (1954). A new glyceraldehyde phosphate dehydrogenase from photosynthetic tissues. Nature, Lond. 173, 1132.

Aubert, J.-P., Mrlhaud, G. \& Millet, J. (1957). L'Assimilation de l'anhydride carbonique par les bactéries chimioautotrophes. Ann. Inst. Pasteur, 92, 515.

Bassham, J. A. \& Calvin, M. (1957). The Path of Carbon in Photosynthesis. Englewood Cliffs, N.J.: Prentice-Hall, Inc.

Bergmann, F. H., Towne, J. C. \& Burris, R. H. (1958). Assimilation of carbon dioxide by hydrogen bacteria. J. biol. Chem. $230,13$.

BüCHER, T. (1947). Über ein phosphatübertragendes Gärungsferment. Biochim. biophys. Acta, 1, 292.

Cohen-Bazire, G., Sistrom, W. R. \& Stanier, R. Y. (1957). Kinetic studies of pigment synthesis by non-sulfur purple bacteria. J. cell. comp. Physiol. 49, 25.

Cutinelli, C., Ehrensvärd, G., Reio, L., Saluste, E. \& Stuernholm, R. (1951). Acetic acid metabolism in Rhodospirillum rubrum under anaerobic conditions 2. Ark. Kemi, 3, 315. 
Frenkel, A. W. (1959). Light-induced reactions of bacterial chromatophores and their relation to photosynthesis. Annu. Rev. Plant Physiol. 10, 53.

Fuller, R. C. \& GibBs, M. (1959). Intracellular and phylogenetic distribution of ribulose 1:5-diphosphate carboxylase and D-glyceraldehyde 3-phosphate dehydrogenases. Plant Physiol. 34, 324.

Gaffron, H. (1933). Über den Stoffwechsel der Schwefelfreien Purpurbakterien. 1. Biochem. Z. $260,1$.

Gaffron, H. (1935). Über den Stoffwechsel der Purpurbakterien. 2. Biochem. Z. 275, 301.

Griss, M. (1952). Triosephosphate dehydrogenase and glucose-6-phosphate dehydrogenase in the pea plant. Nature, Lond. 170, 164.

Glover, J., Kamen, M. D. \& van Genderen, H. (1952). Studies on the metabolism of photosynthetic bacteria. XII. Comparative light and dark metabolism of acetate and carbonate by Rhodospirillum rubrum. Arch. Biochem. 35, 384.

Horecker, B. L., Hurwitz, J. \& Weissbach, A. (1958). Ribulose diphosphate. Biochemical Preparations, 6, 83. Ed. by C. S. Vestling, New York: John Wiley and Sons, Inc.

Kornberg, H. L., Collins, J. F. \& Bigley, D. (1960). The influence of growth substrates on metabolic pathways in Micrococcus denitrificans. Biochim. biophys. Acta, $39,9$.

LASCELles, J. (1956). The synthesis of porphyrins and bacteriochlorophyll by cell suspensions of Rhodopseudomonas spheroides. Biochem. J. 62, 78.

LAscelles, J. (1959). Adaptation to form bacteriochlorophyll in Rhodopseudomonas spheroides: changes in activity of enzymes concerned in pyrrole synthesis. Biochem. $J$. 72, 508.

LAScelles, J. (1960). The synthesis of enzymes concerned in bacteriochlorophyll formation in growing cultures of Rhodopseudomonas spheroides. J. gen. Microbiol. $23,487$.

Lynen, F., Knappe, J., Lorch, E., Jütting, G. \& Ringelmann, E. (1959). Die biochemische Funktion des Biotins. Angerw. Chem. 71, 481.

Monod, J., Pappenheimer, A. M. Jr., \& Cohen-Bazire, G. (1952). La cinétique de la biosynthèse de la $\beta$-galactosidase chez Escherichia coli considérée comme fonction de la croissance. Biochim. biophys. Acta, 9, 648.

NiEL, C. B. van (1941). The bacterial photosyntheses and their importance for the general problem of photosynthesis. Advanc. Enzymol. 1, 263.

NiEL, C. B. vaN (1944). The culture, general physiology, morphology and classification of the non-sulfur purple and brown bacteria. Bact. Rev. 8, 1.

Olson, J. M., Duysens, L. N. M. \& Kronenberg, G. H. M. (1959). Spectrofluorometry of pyridine nucleotide reactions in Chromatium. Biochim. biophys. Acta, 36, 125.

Olson, J. M. \& Amesz, J. (1960). Action spectra for fluorescence excitation of pyridine nucleotide in photosynthetic bacteria and algae. Biochim. biophys. Acta, 37, 14.

Ormerod, J. G. (1956). The use of radioactive carbon dioxide in the measurement of carbon dioxide fixation in Rhodospirillum rubrum. Biochem. J. 64, 373.

PACKer, L. (1958). Respiratory carriers involved in the oxidation of hydrogen and lactate in a facultative autotroph. Arch. Biochem. Biophys. 78, 54.

Quayle, J. R., Fuller, R. C., Benson, A. A. \& Calvin, M. (1954). Enzymatic carboxylation of ribulose diphosphate. J. Amer. chem. Soc. 76, 3610.

Quayle, J. R. \& Keech, D. B. (1959a). Carbon assimilation by Pseudomonas oxalaticus $(\mathrm{OXl})$. 1. Formate and carbon dioxide utilization during growth on formate. Biochem. $J$. $72,623$.

QuAYLe, J. R. \& KeECh, D. B. (1959b). Carbon assimilation by Pseudomonas oxalaticus $(\mathrm{OXl})$. 2. Formate and carbon dioxide utilization by cell-free extracts of the organism grown on formate. Biochem. J. 72, 631.

QuAYle, J. R. \& Keech, D. B. (1960). Carbon assimilation by Pseudomonas oxalaticus $(\mathrm{OXI})$. 3. Oxalate utilization during growth on oxalate. Biochem. J. 75, 515.

Racker, E. (1957). The reductive pentose cycle. 1. Phosphoribulokinase and ribulose diphosphate carboxylase. Arch. Biochem. Biophys. 69, 300.

Smith, L. \& Ramírez, J. (1959). Absorption spectrum changes in photosynthetic bacteria following illumination or oxygenation. Arch. Biochem. Biophys. 79, 233. 
Smith, L., Baltscheffsky, M. \& Olson, J. M. (1960). Adsorption spectrum changes observed on illumination of aerobic suspensions of photosynthetic bacteria. J. biol. Chem. 235, 213.

Stanier, R. Y., Doudoroff, M., Kunisawa, R. \& Contopoulou, R. (1959). The role of organic substrates in bacterial photosynthesis. Proc. nat. Acad. Sci., Wash. 45, 1246.

Stoppani, A. O. M., Fuller, R. C. \& Calvin, M. (1955). Carbon dioxide fixation by Rhodopseudomonas capsulatus. J. Bact. 69, 491.

Trudinger, P. A. (1956). Fixation of carbon dioxide by extracts of the strict autotroph Thiobacillus denitrificans. Biochem. J. 64, 274.

Vishniac, W. \& Santer, M. (1957). The Thiobacilli. Bact. Rev. 21, 195.

Weissbach, A., Smyrniotis, P. Z. \& Horecker, B. L. (1954). Pentose phosphate and $\mathrm{CO}_{2}$ fixation in spinach extracts. J. Amer. chem. Soc. 76, 3611. 